\title{
34. COMPARISON OF CHEMICAL AND MAGNETIC STRATIGRAPHY OF HOLES 396 AND 396B
}

\author{
James H. Natland, Deep Sea Drilling Project, Scripps Institution of Oceanography, La Jolla, California
}

\section{INTRODUCTION}

Successful penetration into igneous basement was achieved by drilling at Site $396\left(22^{\circ} 59^{\prime} \mathrm{N}, 43^{\circ} 31^{\prime} \mathrm{W}\right.$, Mid-Atlantic Ridge) in two holes, 396 and 396B, drilled respectively on Legs 45 (Melson, Rabinowitz, et al., in press) and 46 (Chapter 2, this volume). Hole 396 was the pilot hole for 396B. Total basement penetration in the pilot hole was 96 meters, expending a single bit. The two holes are $\mathbf{5 0 0}$ meters apart (Chapter 2, this volume), with 396 almost due south of 396B. Hole 396B was re-entered five times for a total basement penetration of 255 meters.

Because the holes are so close to each other, it is of some interest to determine whether or not basalt types representing individual eruptive events can be correlated between them. This can give us some idea of the areal distribution of flows at one place on the Mid-Atlantic Ridge, although two holes admittedly are insufficient to resolve this question entirely. By combining chemical identification of basalt types in the two holes with the results of downhole paleomagnetic studies, we can also hopefully gain information about timing and frequency of eruptive events as well as structural modifications of the crust that are important to understand laterally as well as vertically.

\section{LITHOLOGIC UNITS}

The scientific parties of both Legs 45 and 46 identified three types of units in igneous basement: (1) lithologic units, (2) chemical units, and (3) magnetic units. These units are summarized on Figure 1. This figure, and the discussion that follows, are based primarily on the relevant site chapters in this volume and in Volume 45. Briefly, there is only one lithologic unit in Hole 396 . The rocks consist of a fairly uniform sequence of fresh to moderately altered phyric pillow basalts with a multitude of glass zones. Textures range from glassy, through spherulitic, to intersertal, with skeletal and dendritic plagioclases, olivines, and clinopyroxenes well developed. The upper cores contain lithified interpillow sediments (foraminifer-nannofossil limestone). Phenocrysts are plagioclase $(7-15 \%)$ and olivine $(1-3 \%)$ but not clinopyroxene. Some plagioclases have rounded, resorbed outlines.

In Hole 396B, various sparsely phyric (Units 1 and 2) and phyric (Units 4 and 6) basalts were identified. The latter, too, have only plagioclase and olivine phenocrysts. The upper cores also contain interpillow limestones. Units 5 through 8 are complex, with carbonate-cemented palagonite breccia overlying unconsolidated basaltic sand, basaltic sandstone, pillow breccia, and possibly pillow basalt. Recovery was poor in these units. Unit 3 is a fairly massive flow or sill, with fine-grained chill margins, and a coarser interior.

\section{CHEMICAL UNITS}

Chemical units were defined in much the same way on Legs 45 and 46 . One or more samples per core was analyzed onboard ship for major elements and selected trace elements $(\mathrm{Sr}, \mathrm{Zr}, \mathrm{Cr}$, and $\mathrm{Ni}$ ) by $\mathrm{X}$-ray fluorescence spectrometry (Bougault et al., in press, and this volume). Some elements proved more useful than others for discriminating basalt types. $\mathrm{TiO}_{2}$, for example, can be measured with very high precision, and the basalt types at Site 396 (as at Site 395, also drilled on Leg 45) have the interesting and useful property that $\mathrm{TiO}_{2}$ varies extremely little (less than $0.05 \%$ ) in any given chemical unit. The differences between chemical units in $\mathrm{TiO}_{2}$ are generally larger than this by factors of five to ten. By and large, the group of samples analyzed within each chemical unit also has strong coherence (little variation) in one or more of other oxides or trace elements that either support the distinction based on $\mathrm{TiO}_{2}$, or define distinctions sometimes not seen with $\mathrm{TiO}_{2}$. The data can then be used to decide how, if at all, distinct chemical types are related.

The basic definitions of chemical units based on shipboard data are given for Hole 396 in Chapter 7 of Melson, Rabinowitz, et al. (in press) and Bougault et al. (in press). For Hole 396B, they are given in Chapter 2 and in Bougault et al., both this volume. Three chemical types were defined for Hole 396, and six for Hole 396B. Average chemical analyses and the standard deviations for each unit are listed in Table 1 (from Bougault et al., in press, this volume). The reader can judge which oxides or trace elements were useful discriminants from this table. The samples selected for analysis in general are fresh, with low $\mathrm{Fe}_{2} \mathrm{O}_{3} / \mathrm{FeO}$ and low loss on ignition (Bougault et al., in press, this volume). Element mobility during alteration (especially of $\mathrm{MgO}, \mathrm{CaO}$, and $\mathrm{Sr}$ ) is thus considered to be low. Melson (in press), for example, identified the same three chemical units in Hole 396 using electron microprobe analyses of fresh glasses as were defined onboard ship by $\mathrm{X}$-ray fluorescence. The verification of the Hole 396 shipboard chemical stratigraphy by glass probe analyses establishes that alteration was minor and also that the chemical differences are not fundamentally the result of varying concentrations of phenocrysts.

The conventions used for identifying the chemical units on Legs 45 and 46 were different. The Leg 45 convention was to use the mnemonic symbol $\mathrm{P}$ for all phyric basalts (and A for aphyric basalts of Site 395). The shipboard party concluded that the three units thus defined for Hole 396 are not comagmatic, although one unit $(\mathrm{Pb}$ of Figure 1 and 


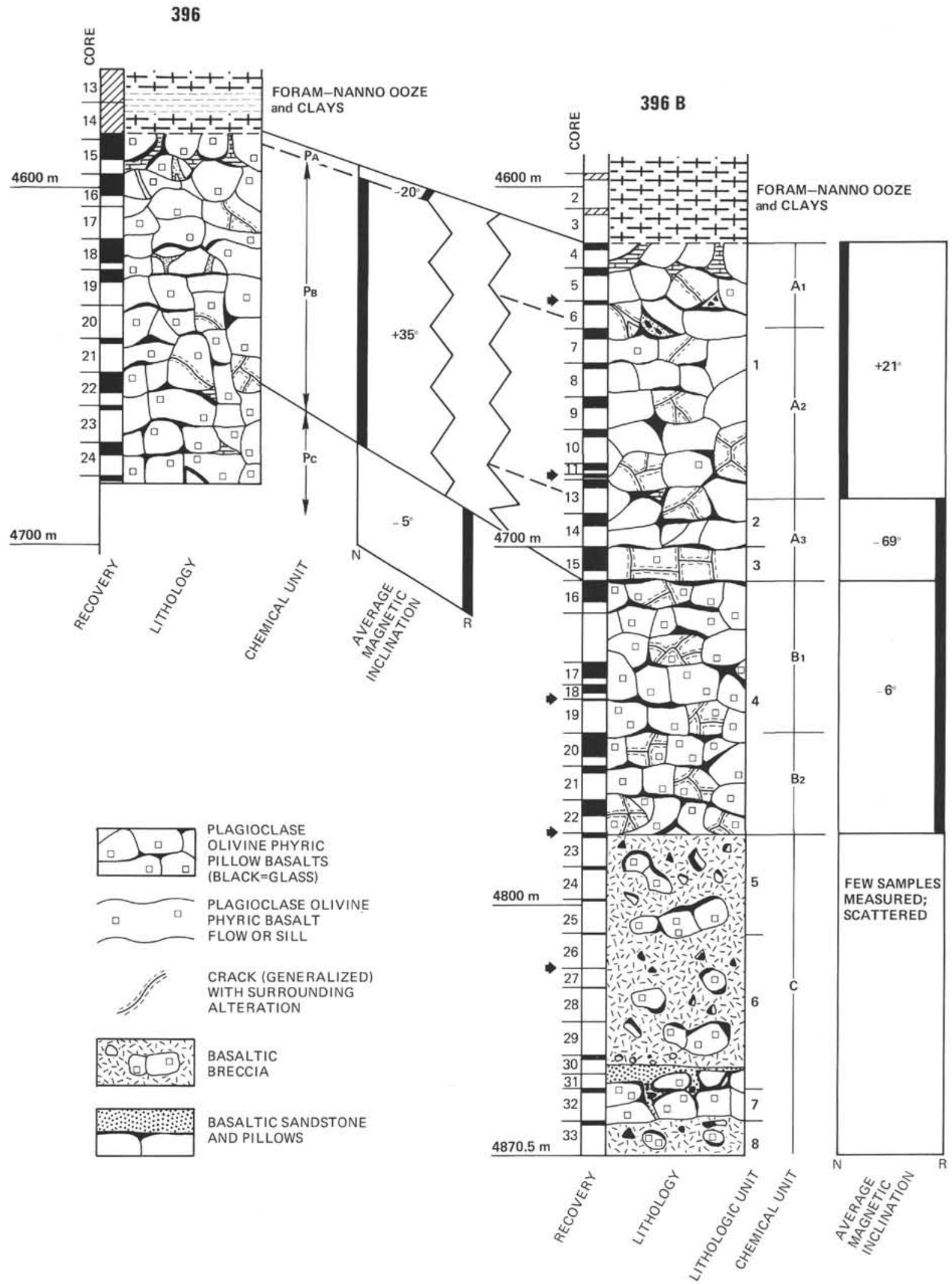

Figure 1. Basement stratigraphy Site 396. Magnetic units are in separate columns to the right of lithologic columns for each hole. Average magnetic inclinations are shown. Normal polarity is indicated by heavy lines on the left side, and reversed polarity by heavy lines on the right side, of the magnetic columns. Correlations between Holes 396 and $396 B$ are shown for the base of the sediment column and the top of Units $P_{C}$ and $B_{1}$. Dashed lines show extensions of $P_{a}, A_{1}$, and $A_{2}$ between the two holes, but broken by the saw-toothed lines. Arrows on $396 B$ indicate depths of each re-entry. 
TABLE 1

Major Element Average Values and Standard Deviations for Chemical Units - Site 396

\begin{tabular}{|c|c|c|c|c|c|c|c|c|c|}
\hline $\begin{array}{l}\text { Major } \\
\text { Elements } \\
(w t \%)\end{array}$ & $\begin{array}{l}P_{b}^{a} \\
(1)^{c}\end{array}$ & $\begin{array}{l}P_{b}{ }^{a} \\
(4)\end{array}$ & $\begin{array}{l}\mathrm{P}_{\mathrm{c}}{ }^{\mathrm{a}} \\
\text { (4) }\end{array}$ & $\begin{array}{l}\mathrm{A}_{1}^{\mathrm{b}} \\
(6)\end{array}$ & $\begin{array}{l}\mathrm{A}_{2}{ }^{\mathrm{b}} \\
(9)\end{array}$ & $\begin{array}{l}\mathrm{A}_{3}{ }^{\mathrm{b}} \\
(7)\end{array}$ & $\begin{array}{l}\mathrm{B}_{1}{ }^{\mathrm{b}} \\
(6)\end{array}$ & $\begin{array}{c}\mathrm{B}_{2}{ }^{\mathrm{b}} \mathrm{q} \\
(5)\end{array}$ & $\begin{array}{l}\mathrm{C}^{\mathrm{b}} \\
\text { (6) }\end{array}$ \\
\hline $\mathrm{SiO}_{2}$ & 49.3 & 49.68 & 49.45 & 49.69 & 50.03 & 49.94 & 49.67 & 49.63 & 49.10 \\
\hline $\mathrm{Al}_{2} \mathrm{O}_{3}$ & 16.25 & $\begin{array}{r}0.13 \\
16.78\end{array}$ & $\begin{array}{r}0.35 \\
16.73\end{array}$ & $\begin{array}{r}0.25 \\
15.59\end{array}$ & $\begin{array}{r}0.17 \\
15.29\end{array}$ & $\begin{array}{r}0.23 \\
15.19\end{array}$ & $\begin{array}{r}0.20 \\
16.91\end{array}$ & $\begin{array}{r}0.29 \\
17.66\end{array}$ & $\begin{array}{r}0.20 \\
15.86\end{array}$ \\
\hline & & 0.10 & 0.15 & 0.31 & 0.13 & 0.19 & 0.13 & 0.24 & 0.19 \\
\hline $\mathrm{Fe}_{2} \mathrm{O}_{3}(\mathrm{t})$ & 9.96 & 9.33 & $\begin{array}{l}9.48 \\
0.16\end{array}$ & 10.15 & 10.53 & 11.00 & 9.45 & 8.73 & $\begin{array}{r}10.44 \\
0.26\end{array}$ \\
\hline $\mathrm{MgO}$ & 7.0 & $\begin{array}{l}8.17 \\
0.31\end{array}$ & $\begin{array}{l}0.16 \\
7.55 \\
0.26\end{array}$ & $\begin{array}{l}0.32 \\
7.93 \\
0.15\end{array}$ & $\begin{array}{l}0.22 \\
7.72 \\
0.28\end{array}$ & $\begin{array}{l}0.24 \\
7.75 \\
0.27\end{array}$ & $\begin{array}{l}0.29 \\
7.78 \\
0.36\end{array}$ & $\begin{array}{l}0.22 \\
7.84 \\
0.53\end{array}$ & $\begin{array}{l}0.26 \\
7.76 \\
0.34\end{array}$ \\
\hline $\mathrm{CaO}$ & 11.57 & $\begin{array}{r}11.98 \\
0.09\end{array}$ & $\begin{array}{r}0.20 \\
12.03 \\
0.07\end{array}$ & $\begin{array}{r}11.83 \\
0.32\end{array}$ & $\begin{array}{r}0.28 \\
11.66 \\
0.14\end{array}$ & $\begin{array}{r}11.12 \\
0.11\end{array}$ & $\begin{array}{r}0.30 \\
12.34 \\
0.22\end{array}$ & 12.66 & $\begin{array}{r}11.51 \\
0.23\end{array}$ \\
\hline $\mathrm{Na}_{2} \mathrm{O}$ & 2.40 & $\begin{array}{l}0.09 \\
2.41 \\
0.07\end{array}$ & $\begin{array}{l}0.07 \\
2.46 \\
0.03\end{array}$ & $\begin{array}{l}0.32 \\
2.56 \\
0.04\end{array}$ & $\begin{array}{l}0.14 \\
2.58 \\
0.08\end{array}$ & $\begin{array}{l}0.11 \\
2.72 \\
0.08\end{array}$ & $\begin{array}{l}0.22 \\
2.40 \\
0.12\end{array}$ & $\begin{array}{l}0.10 \\
2.36 \\
0.08\end{array}$ & $\begin{array}{l}0.23 \\
2.64 \\
0.07\end{array}$ \\
\hline $\mathrm{K}_{2} \mathrm{O}$ & 0.31 & $\begin{array}{l}0.24 \\
0.04\end{array}$ & $\begin{array}{l}0.21 \\
0.05\end{array}$ & $\begin{array}{l}0.24 \\
0.05\end{array}$ & $\begin{array}{l}0.25 \\
0.04\end{array}$ & $\begin{array}{l}0.23 \\
0.08\end{array}$ & $\begin{array}{l}0.22 \\
0.01\end{array}$ & $\begin{array}{l}0.20 \\
0.02\end{array}$ & $\begin{array}{l}0.27 \\
0.07\end{array}$ \\
\hline $\mathrm{TiO}_{2}$ & 1.50 & $\begin{array}{l}1.27 \\
0.02\end{array}$ & $\begin{array}{l}1.29 \\
0.02\end{array}$ & $\begin{array}{l}1.41 \\
0.03\end{array}$ & $\begin{array}{l}1.53 \\
0.02\end{array}$ & $\begin{array}{l}1.64 \\
0.02\end{array}$ & $\begin{array}{l}1.23 \\
0.05\end{array}$ & $\begin{array}{l}1.06 \\
0.07\end{array}$ & $\begin{array}{l}1.51 \\
0.05\end{array}$ \\
\hline Total & 98.29 & 99.86 & 99.20 & 99.40 & 99.59 & 99.55 & 100.00 & 100.14 & 99.09 \\
\hline \multicolumn{10}{|c|}{ Average Values for Trace Elements (ppm) } \\
\hline $\begin{array}{l}\mathrm{Cr} \\
\mathrm{Ni} \\
\mathrm{Sr} \\
\mathrm{Zr}\end{array}$ & $\begin{array}{l}288 \\
111 \\
148 \\
118\end{array}$ & $\begin{array}{r}393 \\
142 \\
156 \\
87\end{array}$ & $\begin{array}{r}290 \\
121 \\
131 \\
97\end{array}$ & $\begin{array}{r}347 \\
136 \\
128 \\
94\end{array}$ & $\begin{array}{l}305 \\
132 \\
139 \\
101\end{array}$ & $\begin{array}{l}277 \\
138 \\
145 \\
120\end{array}$ & $\begin{array}{r}332 \\
133 \\
133 \\
80\end{array}$ & $\begin{array}{r}351 \\
142 \\
136 \\
69\end{array}$ & $\begin{array}{l}349 \\
133 \\
157 \\
104\end{array}$ \\
\hline
\end{tabular}

${ }^{\mathrm{a}}$ Hole 396.

$\mathrm{b}_{\text {Hole 396B. }}$

${ }^{\mathrm{c}}$ No. of samples in parentheses.

Table 1) showed internal chemical variations in $\mathrm{Ni}, \mathrm{Zr}$, and $\mathrm{TiO}_{2}$ which could reflect olivine-controlled fractionation (Melson, Rabinowitz, et al., in press, Chapter 8). $\mathrm{Pb}$ and $\mathrm{Pc}$ were noted to be quite similar, but $\mathrm{Pb}$ has higher $\mathrm{MgO}, \mathrm{Cr}$, $\mathrm{Ni}$, and $\mathrm{Sr}$ than $\mathrm{P}_{c}$. Olivine-controlled fractionation (of $\mathrm{P}_{b}$ to $\mathrm{P}_{c}$ ) would result in still higher $\mathrm{Sr}$ in $\mathrm{P}_{\mathrm{c}}$. Thus the two cannot be comagmatic. Bougault et al. (in press), although in general supporting this conclusion, suggested that $\mathrm{Sr}$ could have been modified by alteration or disequilibrium partitioning between plagioclase and liquid.

The Leg 46 Scientific Party adopted an alphabetic convention to define three major chemical units (Chapter 2, this volume). The upper two of these were divided into sub-units, with numeric subscripts for the sub-units (Figure 1, Table 1). Most contributors to Volume 46 concluded that the units and most sub-units were independent magma batches not relatable by crystal fractionation of the principal phenocryst phases involved (plagioclase and olivine), but there was little agreement on the processes responsible for the differences (tapping of different parts of a magma chamber, mixing of fractionated and unfractionated magmas, resorption, variations in the extent and depth of melting, etc.).

\section{MAGNETIC UNITS}

Magnetic units were defined in the same way on both Legs 45 and 46 (Johnson, in press; Peterson, this volume). The magnetic inclinations of mini-core samples taken from one or more oriented basalt pieces per core were measured. An oriented sample has an external surface cut by coring and a length longer than the core diameter. The average inclinations shown on Figure 1 have small standard deviations $\left( \pm 2-3^{\circ}\right)$, close to the precision of the sampling and measuring techniques on Glomar Challenger. In Hole 396 , the chemical and magnetic units coincide. The average magnetic inclination of Unit $\mathrm{Pb}_{\mathrm{b}}\left(+35^{\circ}\right)$ is close to that of the theoretical dipole value $\left( \pm 40^{\circ}\right)$ for the latitude of the site. The average inclinations of the other two units in Hole 396 are less than this, possibly consequences of post-emplacement tectonic rotation (Johnson, in press). Alternatively, the inclinations are in the range of possible inclinations (for one standard deviation) for the angular dispersion caused by secular geomagnetic variation $\left(18^{\circ}-56^{\circ}\right.$; Johnson, in press).

In Hole 396B, chemical units correspond to magnetic units except for an abrupt change in inclinations within chemical Unit $A_{3}$. The top of Unit $A_{3}$ occurs about midway in Core 13 (at about $220 \mathrm{~m}$ sub-bottom between Samples $13-2,89-91 \mathrm{~cm}$ and $13-3,4-6 \mathrm{~cm})$ and the bottom at the base of Core 15 ( $244.5 \mathrm{~m}$ sub-bottom, or $4709.5 \mathrm{~m}$ below sea level on Figure 1). A sharp change in magnetic inclination (and in fact of polarity) occurs toward the top of Core 14 (between Samples 14-1, 19-21 cm and 14-1, $11-83 \mathrm{~cm})$ at an estimated sub-bottom depth of about 227 meters (based on core recovery). This could vary as much as about 5 meters in either direction. Kirkpatrick (this volume) notes a sharp increase in porosity and decrease in density in the logging records of Hole 396B at about 230 meters sub-bottom, and interprets this to be a fault responsible for the change in inclinations within Unit $A_{3}$. The high negative 
inclinations of the lower part of Unit $\mathrm{A}_{3}$ are beyond the range expected for secular variation. Peterson (this volume) attributes most of the differences between actual and theoretical inclinations $\left( \pm 40^{\circ}\right)$ to fault-block rotation. Since faulting almost certainly occurred in at least this one place in Hole 396B, it is apparent that no clear interpretation of the history of the earth's magnetic field can be made based on the results of this hole, and that fault-block rotation could be responsible for all the deviations from the theoretical inclination that occur. Secular variations and reversals may also have occurred.

Once the possibility of faulting is established, the meaning of the chemical stratigraphy is also less certain. For example, comparing the data on Table 1, chemical Units $A_{2}$ and $C$ can be seen to be virtually identical. Unit $C$ was a poorly recovered basalt breccia, basalt sandstone unit with minor pillows with distinctively high porosity and low density in the logging records (Kirkpatrick, this volume). Magnetic inclinations are scattered. Could Unit C simply be Unit $A_{2}$ repeated in a fault zone?

\section{CORRELATIONS BETWEEN HOLES 396 AND 396B}

Interpreting basalt stratigraphy on the basis of chemical and magnetic data, and then attempting correlations based upon those data, requires enunciation of several points of stratigraphic order. Without biostratigraphic information, we cannot be talking rigorously about time-stratigraphic units. At best, magnetic stratigraphy might give us some idea of the time sequence of events, but at Site 396 the likelihood of faulting eliminates effective use of magnetic stratigraphy. If we identify a chemical type or a range of comagmatic types as the potential product of a single eruptive event, there is a fair possibility that the eruptive event occurred over a period of time, producing timetransgressive lava flows. There is no way of knowing, at Site 396, whether these time periods were long or short with respect to variations in the earth's magnetic field.

For Site 396, then, we shall adopt the following conventions.

1) Chemical units that are indistinguishable between two holes (at least partially overlap in all oxides and trace elements) and have the same, or nearly the same, magnetic inclinations shall be considered part of the same eruptive event whose duration was short compared with secular variation of the earth's magnetic field (i.e., $\leqslant 10^{2}$ years; Johnson, in press).

2) Chemical units that are indistinguishable between two holes or within the same hole but have different inclinations (or stratigraphic positions) will be considered part of the same eruptive event (short with respect to secular variation of the earth's magnetic field), but they have since been relatively rotated or offset by faulting.

3) Similar, but not identical, chemical units may have been part of the same eruptive event if, for example, magmas were being supplied simultaneously from more than one source, or if they reached the surface through different conduit systems. Factors other than crystal fractionation (such as magma mixing, fractional resorption of minerals, especially plagioclase, zone refining, local source heterogeneities, leaving various proportions of residual liquid behind, etc.) may have caused the subtle differences in composition. The interpretation that they were part of the same eruptive event is strengthened if they have the same or similar magnetic inclinations, and the same stratigraphic level in two holes, but is not precluded if they are different. Faulting may have occurred. The eruptive "event" may have been several events closely spaced in time. But since none of these can be demonstrated, no correlation will be shown on Figure 1 and only the possibility of a correlation will be mentioned in the text.

With these considerations in mind, we can see from Table 1 that Unit $P_{c}$ of Hole 396 correlates with Unit $B_{1}$ of Hole 396B, as indicated on Figure 1. The average chemical analyses of these two units are very similar, and they have virtually identical magnetic inclinations. $\mathrm{Pb}_{\mathrm{b}}$ does not correlate with $\mathrm{B}_{1}$ for the same reason cited earlier that distinguishes it from $\mathrm{Pc}_{c}$ (it is too high in $\mathrm{Sr}$ ), and because its magnetic inclination is positive, not negative. $\mathrm{P}_{\mathrm{b}}$ is too low in $\mathrm{TiO}_{2}$ to correlate with $\mathrm{A}_{1}$ or $\mathrm{A}_{2}$.

Unit $\mathrm{Pa}$ (one analysis only) has some chemical characteristics suggesting that it could be related to Unit $A_{1}$ by crystal fractionation (it has lower $\mathrm{Cr}, \mathrm{Ni}, \mathrm{MgO}$, and $\mathrm{CaO}$, plus higher $\mathrm{TiO}_{2}, \mathrm{~K}_{2} \mathrm{O}, \mathrm{Na}_{2} \mathrm{O}, \mathrm{Zr}$, and $\mathrm{Sr}$ ) but it is also distinctly more aluminous, has lower iron, and is reversely, not normally polarized. Fractionation of plagioclase would depress both $\mathrm{CaO}$ and $\mathrm{Al}_{2} \mathrm{O}_{3}$. Additional fractionation of olivine would counteract this, but in the same proportion for $\mathrm{CaO}$ and $\mathrm{Al}_{2} \mathrm{O}_{3}$. Thus the two minerals fractionating together could not produce a simultaneous increase in $\mathrm{Al}_{2} \mathrm{O}_{3}$ and a decrease in $\mathrm{CaO}$. The sediments immediately overlying both $\mathrm{Pa}_{\mathrm{a}}$ and $\mathrm{A}_{1}$ are in the same middle Miocene Discoaster exilis Zone, $13.6( \pm 1.6)$ m.y. On Figure 1, although the chemical differences are only subtle, the two units are shown not to correlate.

Unit $\mathrm{Pb}$ of Hole 396 does not correlate chemically or magnetically with either of Units $A_{2}$ or $A_{3}$ in Hole 396B, even though they occupy the same stratigraphic interval above correlative Units $P_{c}$ and $B_{1}$. This is shown by the saw-toothed break on Figure 1. This means that the flow boundaries of $\mathrm{Pb}, \mathrm{A}_{2}$, and $\mathrm{A}_{3}$ are between the two holes. The simplest interpretation of this depth interval in the two holes is that the differences in inclination could well be the result of faulting within Unit $A_{3}$ as discussed earlier, but the generally positive inclinations suggest eruption of all units within the same positive polarity interval.

The following remarks summarize the possibilities for faults in and between Holes 396 and 396B.

1) Since Unit $P_{c}$ appears to correlate chemically and magnetically with Unit $B_{1}$, and both occur at about the same depth below the sediments, faulting has either not occurred between these units or at least has not affected their relative inclinations.

2) Units $A_{1}, A_{2}$, and $A_{3}$ originally had the same magnetic inclinations, but faulting probably within $A_{3}$ shifted the inclinations of $A_{1}, A_{2}$, and the upper part of $A_{3}$ with respect to the lower part of $A_{3}$.

3) If the differences in inclination between $\mathrm{Pb}_{b}$ and $\mathrm{A}_{1}$ and $A_{2}$ are caused by the fault within Unit $A_{3}$, then the fault extends between the two holes.

4) If, as discussed earlier, $\mathrm{Pa}_{\mathrm{a}}$ and $\mathrm{A}_{1}$ are so similar chemically that they had to be part of the same eruptive 
event (or nearly so), a fault other than that inferred to be within $A_{3}$ has shifted the inclination of $P_{a}$ relative to $A_{1}$. This fault cannot have shifted the inclination of $P_{c}$ relative to $\mathrm{B}_{1}$, nor the inclinations within $\mathrm{P}_{\mathrm{b}}$. The fault would thus most likely be between $\mathrm{P}_{\mathrm{a}}$ and $\mathrm{Pb}_{\mathrm{b}}$ in Hole 396 .

5) A fault at the base of $B_{2}$ may have repeated Unit $A_{2}$ as Unit C.

\section{DISCUSSION}

The poor correlation between Holes 396 and 396B, as well as the probable structural complexities between them reinforce the picture of crustal complexity on the Mid-Atlantic Ridge obtained by drilling. Considering the four sites into igneous basement on the Mid-Atlantic Ridge drilled through Leg 46 where holes can be compared, it appears that the number of correlative units (same chemistry and magnetic inclinations) decreases with increasing separation of holes. Sites 332 and 333, drilled in the same sediment pond $1.8 \mathrm{~km}$ apart, have no correlative units (Aumento, Melson, et al., 1977). Holes 396 and 396B, 500 meters apart, have one correlative unit, but two others in each hole that do not correlate. Four units in Hole 332A do not extend to Hole 332B, 107 meters away but one much thicker unit does (Natland, in press). One other unit in Hole 332B does not reach to Hole $332 \mathrm{~A}$ and has a different polarity than the top of 332A (Hall and Ryall, 1977). Holes 395 and 395A, drilled on Leg 45, are so close together that the difference in their location is not resolvable by satellite fixes (Melson, Rabinowitz, et al., in press). These contain two correlative units, but one unit between these two in Hole 395 does not occur in Hole 395A. Moreover, the average inclination of the correlative units in Hole 395 is $20^{\circ}$ less than in Hole 395A. Apparently this is the result of a fault between the two very closely spaced holes (Johnson, in press).

If Sites 332, 333, 395, and 396 are representative, they suggest an upper limit of perhaps $1 \mathrm{~km}$ for the lineal extent of chemically distinct flows on the slow-spreading Mid-Atlantic Ridge. This is consistent with submersible observations in the axial rift of the FAMOUS area of the Mid-Atlantic Ridge at $37^{\circ} \mathrm{N}$ wherein distinct petrographic types (olivine-phyric, plagioclase-phyric, aphyric, etc.) have an average width (across the axial rift) of about $1 \mathrm{~km}$, and a length (paralleling the rift) of $1-4 \mathrm{~km}$. Each of these petrographic types could consist of several distinct chemical types (in the same way that there are three plagioclase-olivine phyric basalt chemical units in Hole 396). In short, lavas do not flow very far in the median rift of the Mid-Atlantic Ridge.

Because Sites 332, 395, and 396 were drilled on young (Miocene or younger) Mid-Atlantic Ridge oceanic crust, they were drilled in sediment ponds between high ridges (Aumento, Melson, et al., 1977; Melson, Rabinowitz, et al., in press; Chapter 2, this volume). Since the lavas at these sites appear to have been emplaced in an axial rift setting (based on correspondence between the ages of oldest sediments and magnetic "ages'), they apparently underwent uplift to form the inner wall of the median rift, and then subsidence to form the present sediment ponds in which they were drilled. This appears to be accomplished by (1) formation of inward-facing normal faults with throws between 20 meters and 200 meters to form the inner wall (Macdonald and Luyendyk, 1977), and (2)overprinting with outward-facing normal faults to form the undulating relief of the rift mountains (Macdonald and Atwater, 1978). Faults on the inner wall may be very closely spaced (profiles on Macdonald and Luyendyk [1977] show between 1 and 7 faults per hundred meters). In the rift mountains, outward-facing scarps appear to be between 100 and 1000 meters apart (Macdonald and Atwater, 1978). The combination of these two systems of faults no doubt explains much of the structural and magnetic complexity of these holes.

Because of probable complications introduced by faulting, we cannot conclude much of significance concerning the frequency of eruptions at Site 396. This is in contrast to Sites 395 and 332 where the magnetic stratigraphy was coherent enough to identify chemical types that had to erupt during intervals of different polarity. Johnson (in press), comparing the Site 395 data with that of Hall and Ryall (1977) for Site 332, concluded that volcanic events along any given segment of the ridge crest are separated by long periods of no volcanic activity at all, time sufficient for significant secular variations or even reversals in the earth's magnetic field to occur. These time periods are probably on the order of $10^{3}$ or $10^{4}$ years.

On the other hand, petrologic processes at Site 396 must have been very similar to those at Sites 332 and 395. The overriding similarity of all these sites is that they consist mainly of discrete chemical types with very limited internal compositional ranges that cannot be related to each other by crystal fractionation. The subtle compositional differences appear instead to reflect magma mixing (Dungan et al., this volume; Rhodes et al., in press), resorption, variations in the extent of melting, and even source heterogeneities (Bougault et al., in press and this volume). But even though there are subtle compositional differences, the range of final lava products, as expressed for example by $\mathrm{Mg} / \mathrm{Mg}+\mathrm{Fe}$ (Figure 2), is very limited. How narrow this range is can only be appreciated by comparison with other portions of the world's ocean ridge system (e.g., the East Pacific Rise and Iceland on Figure 2). Oceanic ferrobasalts $(\mathrm{Mg} / \mathrm{Mg}+\mathrm{Fe}<0.55)$ form only 5 per cent of all basalts drilled on the Mid-Atlantic Ridge on Legs 37, 45, and 46, whereas they are at least 45 per cent of the rocks drilled through Leg 54 on the East Pacific Rise, and are more than half of the rocks analyzed from Iceland. The purpose of these comparisons in this paper is to show that Site 396 contributes to the broader pattern of petrologic coherence for the Mid-Atlantic Ridge while at the same time it adds to the picture of structural and magnetic complexity. Petrologically, faster spreading ridges and Iceland are fundamentally different, as they are structurally and morphologically. With the completion of Site 396, the first serious comparisons of the various ocean-ridge provinces can begin, based on an adequate idea of the bulk composition of the upper oceanic crust of the Mid-Atlantic Ridge, and on the underlying petrologic complexity. An important aspect of this must be the constraints imposed by chemical and magnetic stratigraphy (as well as correlations between holes) on the frequency, extent, and chemical interrelationships of distinct eruptive events. 

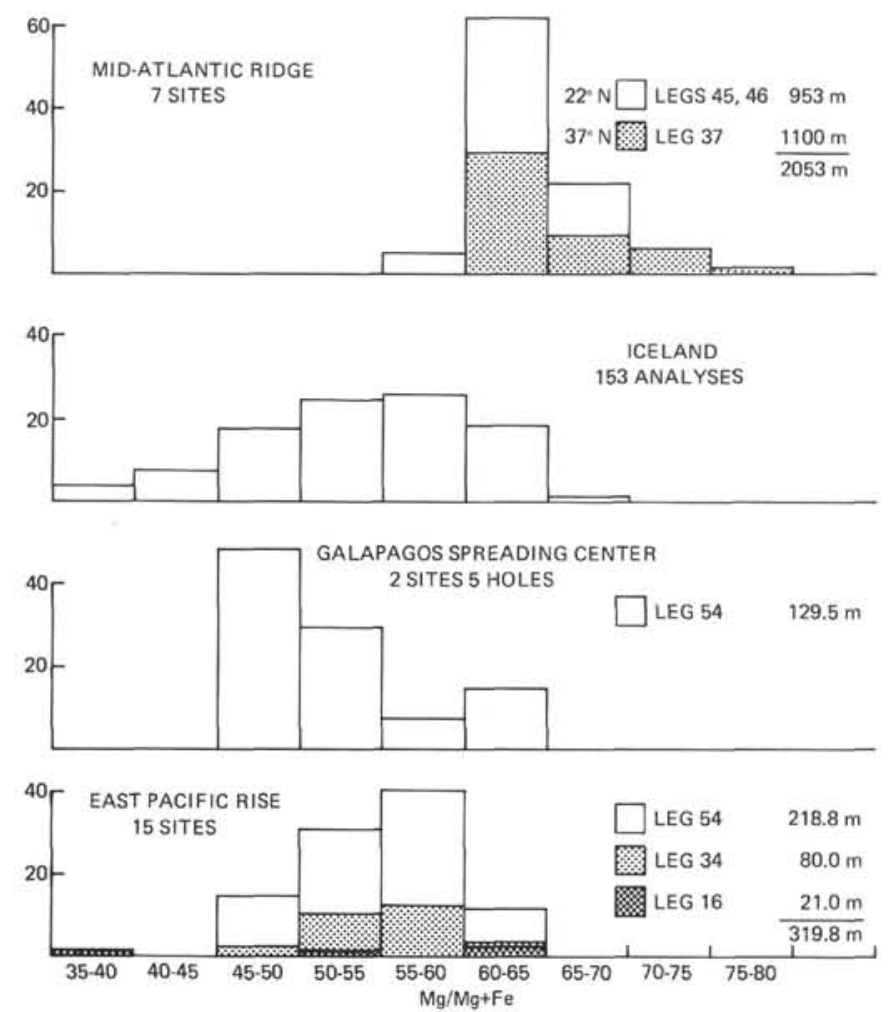
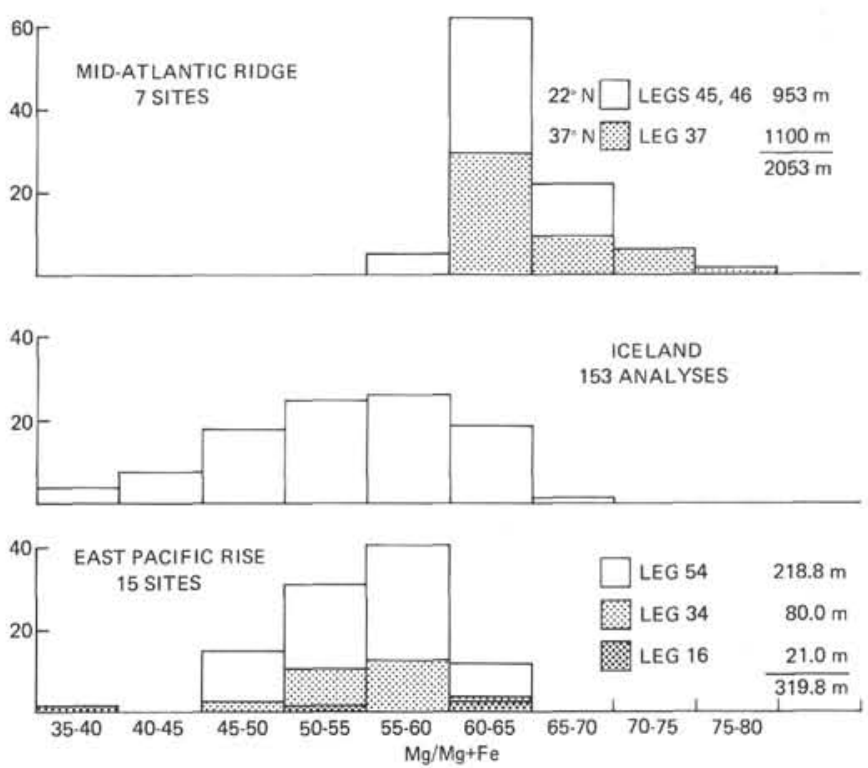

Figure 2. Histogram of $\mathrm{Mg} / \mathrm{Mg}+\mathrm{Fe}$ for DSDP basalts from the Mid-Atlantic Ridge Sites 332-335 (Bougault, 1977), 395 (Bougault et al., in press) and 396 (Boubault et al., this volume), compared with data from the East Pacific Rise (Yeats et al., 1973; Rhodes et al., 1976; and Rosendahl, Hekinian, et al., in preparation). Histogram is constructed by weighting to the thickness of clearly identified chemical units. Iceland data are based on number of analyses (35 from Sigvaldason, $1974 ; 118$ from Jakobssen, 1972).

\section{ACKNOWLEDGMENTS}

I would like to thank J.W. Hawkins, Jr., for reviewing a first draft of this manuscript and R.J. Kirkpatrick for discussions which clarified some of the intricacies of Hole 396B.

\section{REFERENCES}

Aumento, F., Melson, W.G., et al., 1977. Initial Reports of the Deep Sea Drilling Project, v.37: Washington (U.S. Government Printing Office).

Bougault, H., 1977. Major elements, analytical chemistry on board and preliminary results. In Aumento, F., Melson, W.G., et al., Initial Reports of the Deep Sea Drilling Project, v.37: Washington (U.S. Government Printing Office), p. 643-657.

Bougault, H., Joron, L., and Treuil, M., in press. Trace elements: in basalts from $22^{\circ} \mathrm{N}$ and $36^{\circ} \mathrm{N}$ in the Atlantic Ocean: fractional crystallization, partial melting, and heterogeneity of the upper mantle. In Melson, W.G., Rabinowitz, P.D., et al., Initial Reports of the Deep Sea Drilling Project, v.45: Washington (U.S. Government Printing Office).

Hall, J.M. and Ryall, P.J.C., 1977. Paleomagnetism of basement rocks, Leg 37. In Aumento, F., Melson, W.G., et al., Initial Reports of the Deep Sea Drilling Project, v. 37: Washington (U.S. Government Printing Office), p. 425-445.

Jakobssen, S.P., 1972. Chemistry and distribution pattern of Recent basaltic rocks in Iceland, Lithos, v. 5, p. 365-386.

Johnson, H.P., in press. Paleomagnetism of igneous rock samples, DSDP Leg 45. In Melson, W.G., Rabinowitz, P.D., et al., Initial Reports of the Deep Sea Drilling Project, v.45: Washington (U.S. Government Printing Office).

Macdonald, K.C. and Atwater, T.M., 1978. Evolution of ocean ridges, Earth Planet. Sci. Lett., v. 39, p.319-327.
Macdonald, K.C. and Luyendyk, B., 1977. Deep-tow studies of the structure of the Mid-Atlantic Ridge crest near lat. $37^{\circ} \mathrm{N}$, Geol. Soc. Am. Bull., v. 88, p.621-636.

Melson, W.G., in press. Chemical stratigraphy of Leg 45 basalts: electron probe analyses of glasses. In Melson, W.G., Rabinowitz, P.D., et al., Initial Reports of the Deep Sea Drilling Project, v. 45: Washington (U.S. Government Printing Office).

Melson, W.G., Rabinowitz, P.D., et al., in press. Initial Reports of the Deep Sea Drilling Project, v.45: Washington (U.S. Government Printing Office).

Natland, J., in press. Comparison of chemical and magnetic stratigraphy of basement rocks at DSDP Sites 332 and 395. In Melson, W.G., Rabinowitz, P.D., et al., Initial Reports of the Deep Sea Drilling Project, v.45: Washington (U.S. Government Printing Office).

Rhodes, J.M., Blanchard, D.P., Rodgers, K.V., Jacobs, J.W., and Brannon, J.C., 1976. Petrology and chemistry of basalts from the Nazca Plate: Part 2 - major and trace element chemistry. In Yeats, R.S., Hart, S.R., et al., Initial Reports of the Deep Sea Drilling Project, v.34: Washington (U.S. Government Printing Office), p. 239-244.

Rosendahl, B.R., Hekinian, R., et al., in preparation. Initial Reports of the Deep Sea Drilling Project, v.54: Washington (U.S. Government Printing Office).

Sigvaldason, G.E., 1974. Basalts from the center of the assumed Icelandic mantle plume, J.Petrol., v. 15, p.497-524.

Yeats, R.S., Forbes, W.C., Heath, G.R., and Scheidegger, K.F., 1973. Petrology and geochemistry of DSDP Leg 16 basalts, eastern equatorial Pacific. In van Andel, T.H., Heath, G.R., et al., Initial Reports of the Deep Sea Drilling Project, v.16: Washington (U.S. Government Printing Office), p.617-640. 